\title{
Combined effects of salinity, temperature and food on early development of the polychaete Hydroides elegans
}

\author{
Jian-Wen Qiu*, Pei-Yuan Qian \\ Department of Biology, Hong Kong University of Science and Technology, Clear Water Bay, Kowloon, Hong Kong
}

\begin{abstract}
Effects of salinity, temperature and food concentration on early development of the polychaete Hydroides elegans (Haswell) were examined in 4 laboratory experiments. Three 2 -factor experiments tested the effects of salinity $(15$ to $35 \%)$ and temperature $\left(15\right.$ to $\left.30^{\circ} \mathrm{C}\right)$ on the survival and duration of development of $H$. elegans from newly-released oocyte to 2-cell, 2-cell to blastula, and blastula to trochophore stages respectively. A fourth 3-factor experiment tested the effects of salinity (15 to $35 \%)$, temperature $\left(15\right.$ to $\left.30^{\circ} \mathrm{C}\right)$, and concentration of the single-cell alga Isochrysis galbana $\left(0\right.$ to $10^{\circ}$ cells $\mathrm{ml}^{-1}$ ) on survival, settlement, and duration of development from trochophore to newly-settled juvenile. Within the experimental range, temperature had no effect on survivorship, but low temperature led to longer duration of development. Low salinity reduced survivorship and settlement, and lengthened the duration of development. Low food concentration reduced survivorship and settlement, and lengthened the duration of development from trochophore to newly-settled juvenile. At concentrations $\leq 10^{3}$ cells $\mathrm{ml}^{-1},>35 \%$ larvae survived through the $10 \mathrm{~d}$ experiment but lost their ability to become competent. Percentages of trochophores reaching settlement were similar at $10^{4}, 10^{5}$, and $10^{6}$ cells $\mathrm{ml}^{-1}$. Duration of development was shortest at concentrations of $10^{5}$ cells $\mathrm{ml}^{-1}$, while trochophores at $10^{4}$ and $10^{6}$ cells $\mathrm{ml}^{-1}$ had similar but longer durations of development. Our data suggest that in Hong Kong waters, the decrease in salinity during the summer seems to override the benefits of high temperature and to be responsible for the decline in $H$. elegans settlement. The increase in phytoplankton concentration from early spring to early summer may contribute to the formation of settlement peaks. Temperature, however, does not seem to be a limiting factor for early development and settlement of $H$. elegans.
\end{abstract}

KEY WORDS: Hydroides $\cdot$ Development $\cdot$ Salinity $\cdot$ Temperature $\cdot$ Food

\section{INTRODUCTION}

Hydroides elegans (Haswell) (Polychaeta: Serpulidae) is a tube-building polychaete species conspicuous in tropical and subtropical coastal fouling communities. In most places, settlement of $H$. elegans peaks in summer or autumn (Skerman 1958', Wisley 1958', Reish 1961', Kawahara 1969, Li et al. 1982, Zhang et al. 1984). In Hong Kong, however, settlement of $H$. elegans peaks in early spring to early summer (Greene \& Morton 1976, Hon 1978, Qian unpubl. data) This difference in settlement time suggests that reproduction

\footnotetext{
·E-mall: bojwqiu@usthk.ust.hk
}

and recruitment of $H$. elegans in Hong Kong waters may be influenced by environmental factors specific to this area.

In the past several decades, laboratory studies on Hydroides spp. have mainly focused on systematics (Zibrowius 1973, Imajima 1976, FauchaId 1977, KnightJones et al. 1991, ten Hove et al. 1991), oogenesis and fertilization (Nordbaek 1956), maturation (Leone 1970), light reaction (Wisley 1958, Miura \& Tajihara 1984), tube formation (Hedley 1956), salinity tolerance in adults (Hill 1967, Mak \& Huang 1982, Mohan \& Aruna 1994), larval settlement (Scheltema et al. 1981,

${ }^{1} H$. elegans was identified as $H$. norvegica (see ten Hove 1974, Imajima 1976 for reviews) 
Hurlbut 1991, Hadfield et al. 1994), and description of early life history (Haswell 1888, Wisely 1958, Miura \& Kajihara 1981). Less attention has been paid to the mechanism by which environmental factors such as temperature, salinity, and food availability affect embryonic and larval development, and consequently influence larval settlement and population dynamics in the field

Marine invertebrate larvae are usually more sensitive to stress than adults and juveniles of the same species, and such sensitivity may help us explain seasonal or annual variations in recruitment success in the field (cf. reviews by Kinne 1970, 1971, Pechenik 1987, Strathmann 1987). The objectives of this study were to examine the developmental sensitivity of Hydroides elegans to environmental factors and to determine if the results on developmental sensitivity explain the settlement and population dynamics patterns observed in Hong Kong waies. Specifically, we examined how temperature and salinity influence embryonic development (from newly-released oocyte to the hatching of trochophore) and how temperature, salinity and food concentration affect larval development (from trochophore to newly-settled juvenile) of $H$. elegans.

\section{MATERIAL AND METHODS}

Rearing procedures. Procedures for obtaining oocytes and sperm were adopted from Hadfield et al. (1994). Hydroides elegans attached to nylon ropes in Port Shelter, Hong Kong $\left(22^{\circ} 19^{\prime} \mathrm{N}, 114^{\circ} 16^{\prime} \mathrm{W}\right)$ were brought back to the laboratory on March 20, 1996 (salinity and temperature in the field: $21^{\circ} \mathrm{C}$ and $35 \%$, respectively). Tubes containing live worms were carefully removed from the ropes, placed individually into petri dishes containing $10 \mathrm{ml}, 0.22 \mu \mathrm{m}$ filtered seawater (salinity: $35 \%$ ), and gently broken up in the laboratory where temperature was $22^{\circ} \mathrm{C}$. Both males and females released gametes into the seawater within. $15 \mathrm{~min}$. For the following experiments, distinct stages developed from the same batch of gametes were used: newly-released oocyte, 2-cell, blastula, and trochophore (Table 1). Oocytes from 4 females and sperm from 3 males were combined for the experiments. To examine effects of salinity and temperature on fertilization and first cleavage, the newly-released oocytes were transferred into small dishes with $10 \mathrm{ml}$ seawater, and $50 \mu \mathrm{l}$ of seawater containing sperm was pipetted into the dishes. The cultures were maintained at selected salinities and temperatures (Expt I). Meanwhile, the newly-released oocytes were also transferred into a beaker containing $600 \mathrm{ml}$ seawater, and $3 \mathrm{ml}$ seawater containing sperm were pipetted into the beaker where fertilization took place. When the fer- tilized eggs reached the 2-cell embryo, blastula, and trochophore stages, they were used in Expts II, III, \& IV, respectively. Two-cell embryos and blastulae were transferred into small dishes with $10 \mathrm{ml}$ filtered seawater, and maintained at selected salinities and temperatures (Expts II \& III, respectively). Early trochophores were transferred into dishes with $10 \mathrm{ml}$ filtered seawater, and maintained at selected food concentrations, salinities and temperatures (Expt IV). A previous study had shown that at $20^{\circ} \mathrm{C}$, it takes approximately $1 \mathrm{~h}$ for development from fertilization to 2 -cell, $4 \mathrm{~h}$ from 2-cell to blastula, $8 \mathrm{~h}$ from blastula to trochophore and $6 \mathrm{~d}$ from trochophore to competence (Wisely 1958). To allow for flexibility in time of development under different salinity and temperature treatments, our experiments for these 4 stages were run for considerably longer periods ( $12 \mathrm{~h}, 24 \mathrm{~h}, 36 \mathrm{~h}$, and $10 \mathrm{~d}$, respectively) The experimental ranges in salinity (15 to $35 \%$ ) and temperature $\left(15\right.$ to $\left.30^{\circ} \mathrm{C}\right)$ were comparable to those encountered in the field (Morton \& Morton 1983). The single-cell chrysophyte Isochrysis galbana (Tahitian strain) at exponential phase was used to feed the trochophores. Isochrysis galbana concentrations of 0 to $10^{6}$ cells $\mathrm{ml}^{-1}$ were selected to cover the full range of food concentrations encountered in the field. Setup of the 4 experiments is detailed below and summarized in Table 1

Expt I: Newly-released oocyte to 2-cell. Expt I was designed to examine how salinity and temperature affect survival and duration of development of newlyreleased oocytes. The experimental setup followed a 2 -factor design: combinations of 4 temperature levels $\left(15,20,25,30^{\circ} \mathrm{C}\right)$ and 5 salinity levels $(15,20,25,30$, $35 \%$ o). These salinities and temperatures were obtained by diluting filtered natural seawater ( $35 \%$ ) with double-distilled water, and were placed into incubators (Powers Scientific SD33SE) at the 4 designated temperatures. Each of the 20 treatments consisted of 3 replicates, each replicate with 40 oocytes; a total of 2400 newly-released oocytes were used. Developmental stages were checked every half hour after onset of the experiment, until the fertilized oocytes had undergone fertilization and cleavage or disintegrated in $12 \mathrm{~h}$.

Expt II: Two-cell to blastula. Expt II was designed to examine the effects of salinity and temperature on survival and duration of development of 2-cell embryos. The experimental design was the same as in Expt I. Cultures were checked at $3,4,5,6,8,10,12,14,16$ and $24 \mathrm{~h}$ after the onset of experiment, until the 2-cell embryos had developed into blastulae or disintegrated in $24 \mathrm{~h}$.

Expt III: Blastula to trochophore. Expt III was designed to examine the effects of salinity and temperature on survival and duration of development of blastulae. The experimental design was the same as in 
Table 1. Experimental protocols and schedules

\begin{tabular}{|c|c|c|c|c|c|c|}
\hline $\begin{array}{l}\text { Experi- } \\
\text { ment }\end{array}$ & $\begin{array}{c}\text { Stage } \\
\text { at } \\
\text { onset }\end{array}$ & $\begin{array}{l}\text { Experi- } \\
\text { mental } \\
\text { period (d) }\end{array}$ & Design & \multicolumn{3}{|c|}{$\begin{array}{l}\text { Experimental regime } \\
\text { Sal. Temp. Food } \\
(\% \circ)\left({ }^{\circ} \mathrm{C}\right)\left(\text { cells } \mathrm{ml}^{-1}\right)\end{array}$} \\
\hline I & $\begin{array}{l}\text { Newly- } \\
\text { released } \\
\text { oocyte }\end{array}$ & 0.5 & 2-factor & $\begin{array}{l}35 \\
30 \\
25 \\
20 \\
15\end{array}$ & $\begin{array}{l}30 \\
25 \\
20 \\
15\end{array}$ & \\
\hline II & 2-cell & 1 & 2-factor & $\begin{array}{l}35 \\
30 \\
25 \\
20 \\
15\end{array}$ & $\begin{array}{l}30 \\
25 \\
20 \\
15\end{array}$ & \\
\hline III & Blastula & 1.5 & 2-factor & $\begin{array}{l}35 \\
30 \\
25 \\
20 \\
15\end{array}$ & $\begin{array}{l}30 \\
25 \\
20 \\
15\end{array}$ & \\
\hline IV & $\begin{array}{l}\text { Trocho- } \\
\text { phore }\end{array}$ & 10 & 3-factor & $\begin{array}{l}35 \\
30 \\
25 \\
20 \\
15\end{array}$ & $\begin{array}{l}30 \\
25 \\
20 \\
15\end{array}$ & $\begin{array}{c}10^{6} \\
10^{5} \\
10^{4} \\
10^{3} \\
10^{2} \\
0\end{array}$ \\
\hline
\end{tabular}

Expt I. The cultures were checked at 8, 10, 12, 24 and $36 \mathrm{~h}$ after the onset of experiment, until the blastulae had developed into trochophores or disintegrated in $36 \mathrm{~h}$.

Expt IV: Trochophore to newly-settled juvenile. Expt IV was designed to examine the effects of food concentration, salinity and temperature on survivorship, duration of development of trochophores, and percent trochophores that settled. Experimental setup followed a 3-factor design: combinations of 6 Isochrysis galbana concentrations $10,10^{2}, 10^{3}, 10^{4}, 10^{5}$, and $10^{6}$ cells $\left.\mathrm{ml}^{-1}\right), 4$ temperature levels $(15,20,25$, and $\left.30^{\circ} \mathrm{C}\right)$ and 5 salinity levels $(15,20,25,30$, and $35 \%)$. Each of the 120 treatments consisted of 2 replicates, each replicate with 20 oocytes; a total of 4800 trochophores were used. Larvae were transferred to fresh media every $2 \mathrm{~d}$. At each transfer, numbers of surviving larvae were counted. Previous research indicated that Hydroides elegans larvae become competent 6 to $8 \mathrm{~d}$ post-fertilization (Wisely 1958, Hadfield et al. 1994) and preferentially settled on biologically filmed surfaces (Hadfield et al. 1994). Therefore, starting on Day 2 of the experiment, dishes coated with $2 \mathrm{~d}$ old film obtained by soaking dishes in fresh seawater were used to induce settlement. These dishes were then checked daily and the numbers of newly-settled juveniles were counted. Percentage of larvae settled in each dish was calculated as the total numbers of settled juveniles divided by 20 (the total number of trochophore larvae at the beginning of experiment) times 100
At the end of the $10 \mathrm{~d}$ experiment, over $35 \%$ of the larvae in the $\leq 10^{3}$ cells $\mathrm{ml}^{-1}$ treatments survived (except at salinity of $15 \%$ where trochophores all died) but did not grow well. Isochrysis galbana at a concentration of $10^{5}$ cells $\mathrm{ml}^{-1}$ were fed to these larvae for an additional $7 \mathrm{~d}$, to test whether the effect of starvation was reversible.

Statistical analysis. Since the data (survivorship, percent reaching settlement, and duration of development) did not meet the normality assumption of parametric analysis, they were analyzed using nonparametric statistics. This was done by transforming values to ranks and then applying parametric statistics on the data, as described in Zar (1984) and SAS (1988). A 2-way ANOVA (analysis of variance) (Zar 1984) was used to detect salinity and temperature effects on duration of development and survivorship in Expts I, II, and III. A 3-way ANOVA (Zar 1984) was used to analyze food, salinity and temperature effects on survivorship, percent settlement, and duration of development of trochophores in Expt IV. The Tukey multiple comparisons test (Zar 1984) was used to compare treatment means in cases where factors did not significantly interact. When interaction between (among) factors was significant ( $p>0.05)$, the influence of each factor on treatment means was tested at fixed levels of the other factor(s).

\section{RESULTS}

\section{Expt I: Newly-released oocyte to 2-cell}

Although the experiment was run for only $12 \mathrm{~h}$, all oocytes that failed to undergo fertilization and cleavage were dead and had disintegrated within this period.

Temperature $\left(15\right.$ to $\left.30^{\circ} \mathrm{C}\right)$ had no effect on survivorship from newly-released oocyte to 2-cell (Table 2 , Fig. 1A). However, duration of development was significantly longer in the $15^{\circ} \mathrm{C}$ treatment than in the 3 higher temperature treatments (Fig. 1B).

Salinity had a significant influence on both survivorship and duration of development from newlyreleased oocyte to 2 -cell (Table 2). At salinities $\leq 20 \%$, none of the newly-released oocytes attained first cleavage. At $25 \%, 85$ to $90 \%$ oocytes successfully developed into 2 -cell. At 30 and $35 \%$, over $97 \%$ developed into 2-cell (Fig. 1A). The duration of development was longer at $25 \%(2.00 \pm 0.59 \mathrm{~h})$ than at 30 and $35 \%(0.88 \pm 0.31 \mathrm{~h}$ and $0.73 \pm 0.29 \mathrm{~h}$, respectively) (Fig. 1B).

No interaction between temperature and salinity on survivorship or duration of development was detected in the experiment (Table 2, Fig 1B). 


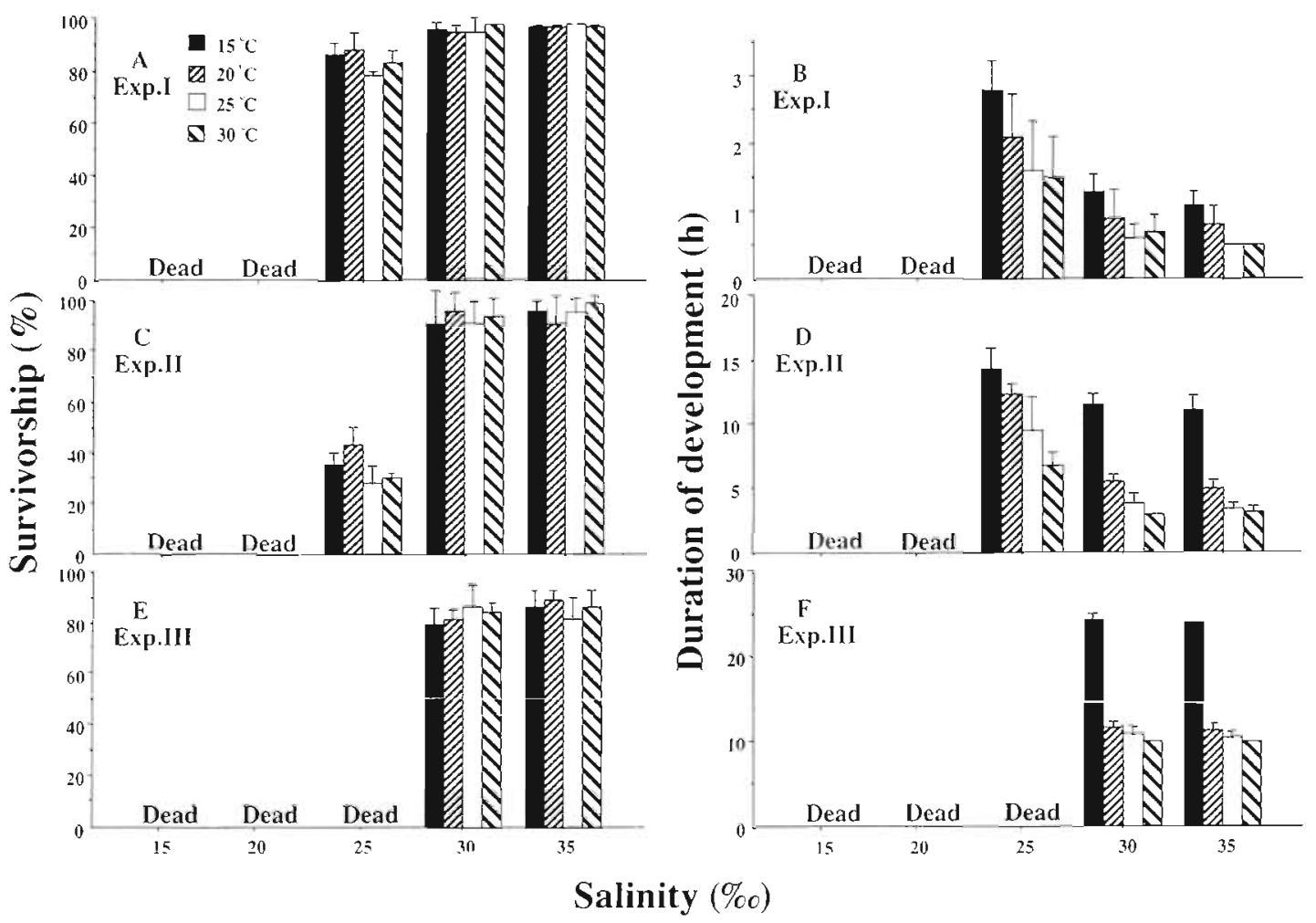

Fig. 1. Hydroides elegans. Effects of salinity and temperature on fertilization and embryonic development. Expt I: Newlyreleased oocyte to 2-cell. (A) Survivorship; (B) duration of development. Oocytes all died at salinities $\leq 20 \%$. Expt II: 2 -cell to blastula. (C) Survivorship; (D) duration of development. Two-cell embryos all died at salinities $\leq 20 \%$. Expt III: Blastula to trochophore. (E) Survivorship; (F) duration of development. Blastulae all died at salinities $\leq 25 \%$. Data are plotted as mean + SD of 3 replicate cultures (each started with 40 individuais)

\section{Expt II: Two-cell to blastula}

Temperature $\left(15\right.$ to $\left.30^{\circ} \mathrm{C}\right)$ did not affect survivorship during development from 2-cell stage to blastula (Table 2, Fig. 1C). However, duration of development was the longest in the $15^{\circ} \mathrm{C}$ treatment, and progressively shorter with increasing temperature (Fig. 1D)

Salinity strongly affected survivorship and duration of development from 2-cell to blastula (Table 2). None of the 2-cell embryos had gone through subsequent cleavages at salinities $\leq 20 \%$. At $25 \%$, about $34 \%$ of the 2-cell embryos successfully developed into blastulae. At 30 and $35 \%$, over $90 \%$ of the 2-cell embryos successfully developed into blastulae (Fig. 1C). Duration of development was longer at $25 \%$ than at 30 and $35 \%$ (Fig. 1D).

No interaction between temperature and salinity on survivorship was detected in Expt II (Table 2). However, interaction of temperature and salinity on duration of development were observed, with the quickest development achieved under high temperature and high salinity conditions (Table 2, Fig. 1D).

\section{Expt III: Blastula to trochophore}

Survivorship during development from blastula to trochophore was not affected by temperature (15 to $30^{\circ} \mathrm{C}$ ) (Table 2, Fig. 1E). However, duration of development was longest in the $15^{\circ} \mathrm{C}$ treatment, and progressively shorter with increasing temperature (Table 2, Fig. 1F).

Salinity significantly affected survivorship (Table 2). None of the blastulae developed to trochophores at salinities $\leq 25 \%$. At 30 and $35 \%$, over $83 \%$ of the blastulae developed into trochophores (Fig. 1E). Duration of development was similar at 30 and 35\% (Fig. 1F).

Temperature and salinity had no interactive affect on survivorship or duration of development (Table 2 , Fig. 1E, F).

\section{Expt IV: Trochophore to newly-settled juvenile}

Survivorship of trochophores was not significantly affected by temperature $\left(15\right.$ to $30^{\circ} \mathrm{C}$ ) (Table 3, Fig. 2). However, both the percent reaching settlement and 
Table 2. Hydroides elegans. Summary of 2-way ANOVA results on effects of salinity and temperature on survivorship and duration of development in fertilization and embryonic development. When there is no interaction between factors, values that do not differ at 0.05 level in Tukey tests are joined by an underline. NS: not significant; NA: data not available due to mor tality of entire treatment

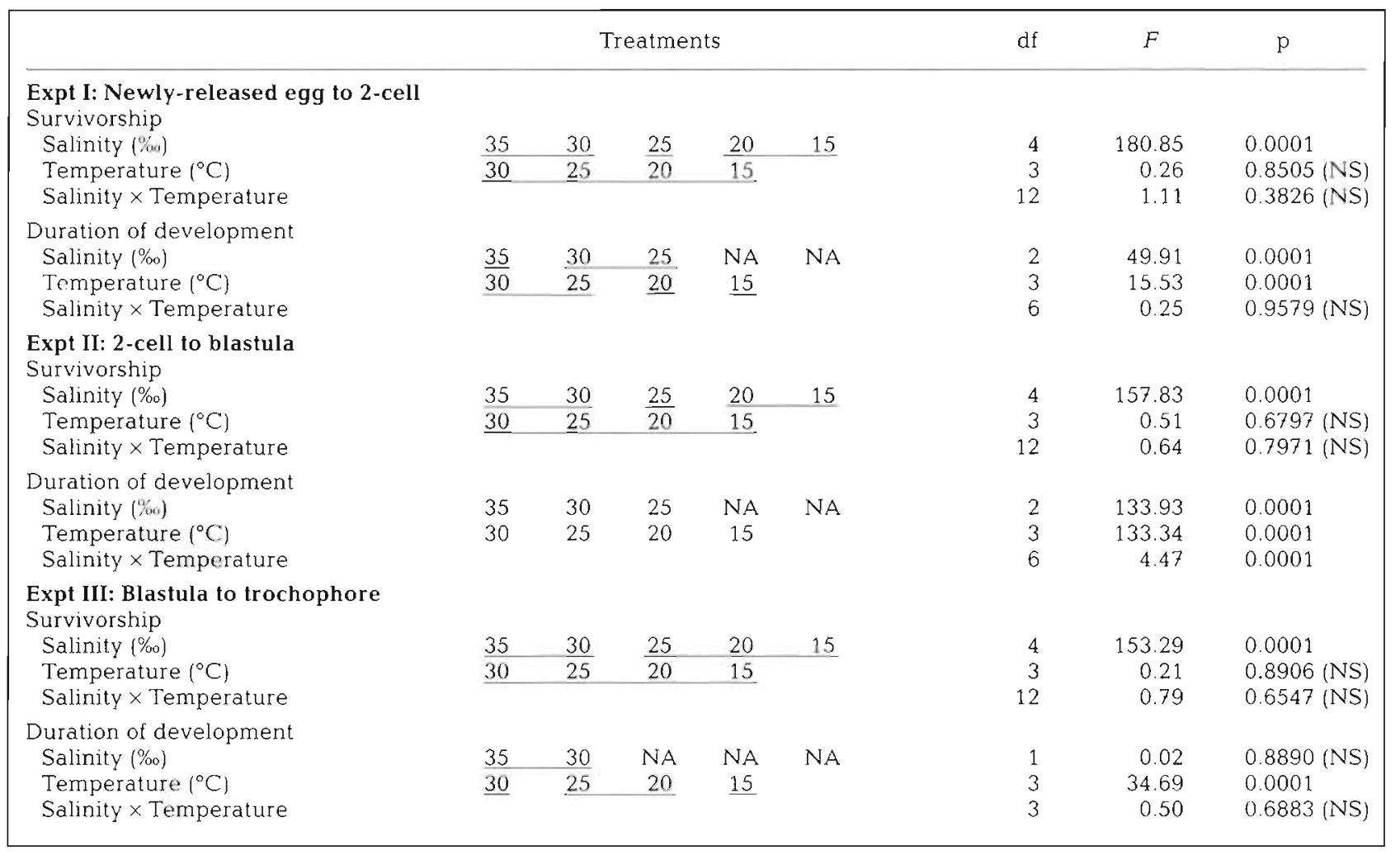

Table 3. Hydroides elegans. Summary of 3-way ANOVA results for Expt IV on effects of salinity and temperature, and food, on survivorship, percent reaching settlement, and duration of development in trochophores. When there is no interaction between factors, values that do not differ at 0.05 level in Tukey tests are joined by an underline. NS: not significant; NA: data not available due to mortality of entire treatment

\begin{tabular}{|c|c|c|c|c|c|c|c|c|c|}
\hline \multirow{2}{*}{ Survivorship } & \multicolumn{6}{|c|}{ Treatments } & \multirow{3}{*}{$\begin{array}{r}\mathrm{df} \\
5\end{array}$} & \multirow{3}{*}{$\begin{array}{c}F \\
56.25\end{array}$} & \multirow{2}{*}{$\mathrm{p}$} \\
\hline & & & & & & & & & \\
\hline Food ration (cells $\mathrm{ml}^{-1}$ ) & $10^{6}$ & $10^{5}$ & $10^{4}$ & $10^{3}$ & $10^{2}$ & 0 & & & 0.0001 \\
\hline Salinity $(\% \circ)$ & 35 & 30 & 25 & 20 & 15 & & 4 & 370.47 & 0.0001 \\
\hline Temperature $\left({ }^{\circ} \mathrm{C}\right)$ & 30 & 25 & 20 & 15 & & & 3 & 2.48 & 0.0643 (NS) \\
\hline Food $\times$ Salinity & & & & & & & 20 & 6.40 & 0.0001 \\
\hline Food $\times$ Temperature & & & & & & & 15 & 0.32 & 0.9919 (NS) \\
\hline Salinity $\times$ Temperature & & & & & & & 12 & 1.90 & 0.0407 \\
\hline Food $\times$ Salinity $\times$ Temperature & & & & & & & 60 & 0.43 & 0.9998 (NS) \\
\hline Percent reaching settlement & & & & & & & & & \\
\hline Food ration (cells $\mathrm{ml}^{-1}$ ) & $10^{6}$ & $10^{5}$ & $10^{4}$ & NA & NA & NA & 2 & 0.33 & $0.7720(\mathrm{NS})$ \\
\hline Salinity $(\% \circ)$ & 35 & 30 & 25 & 20 & NA & & 3 & 44.05 & 0.0001 \\
\hline Temperature $\left({ }^{\circ} \mathrm{C}\right)$ & 30 & 25 & 20 & 15 & & & 3 & 3.40 & 0.0251 \\
\hline Food $\times$ Salinity & & & & & & & 6 & 0.54 & 0.7779 (NS) \\
\hline Food $\times$ Temperature & & & & & & & 6 & 0.10 & $0.9960(\mathrm{NS})$ \\
\hline Salinity $\times$ Temperature & & & & & & & 9 & 1.03 & 0.4277 (NS) \\
\hline Food $\times$ Salinity $\times$ Temperature & & & & & & & 18 & 0.21 & 0.9997 (NS) \\
\hline Duration of́ development & & & & & & & & & \\
\hline Food ration (cells $\mathrm{ml}^{-1}$ ) & $10^{6}$ & $10^{5}$ & $10^{4}$ & $\mathrm{NA}$ & NA & NA & 2 & 13.37 & 0.0001 \\
\hline Salinity $(\%)$ & 35 & 30 & 25 & 20 & NA & & 3 & 77.24 & 0.0001 \\
\hline Temperature $\left({ }^{\circ} \mathrm{C}\right)$ & 30 & 25 & 20 & 15 & & & 3 & 103.68 & 0.0001 \\
\hline Food $\times$ Salinity & & & & & & & 6 & 14.29 & 0.0001 \\
\hline Food $\times$ Temperature & & & & & & & 6 & 21.21 & 0.0001 \\
\hline Salinity $\times$ Temperature & & & & & & & 9 & 8.14 & 0.0407 \\
\hline Food $\times$ Salinity $\times$ Temperature & & & & & & & 18 & 2.87 & 0.0001 \\
\hline
\end{tabular}




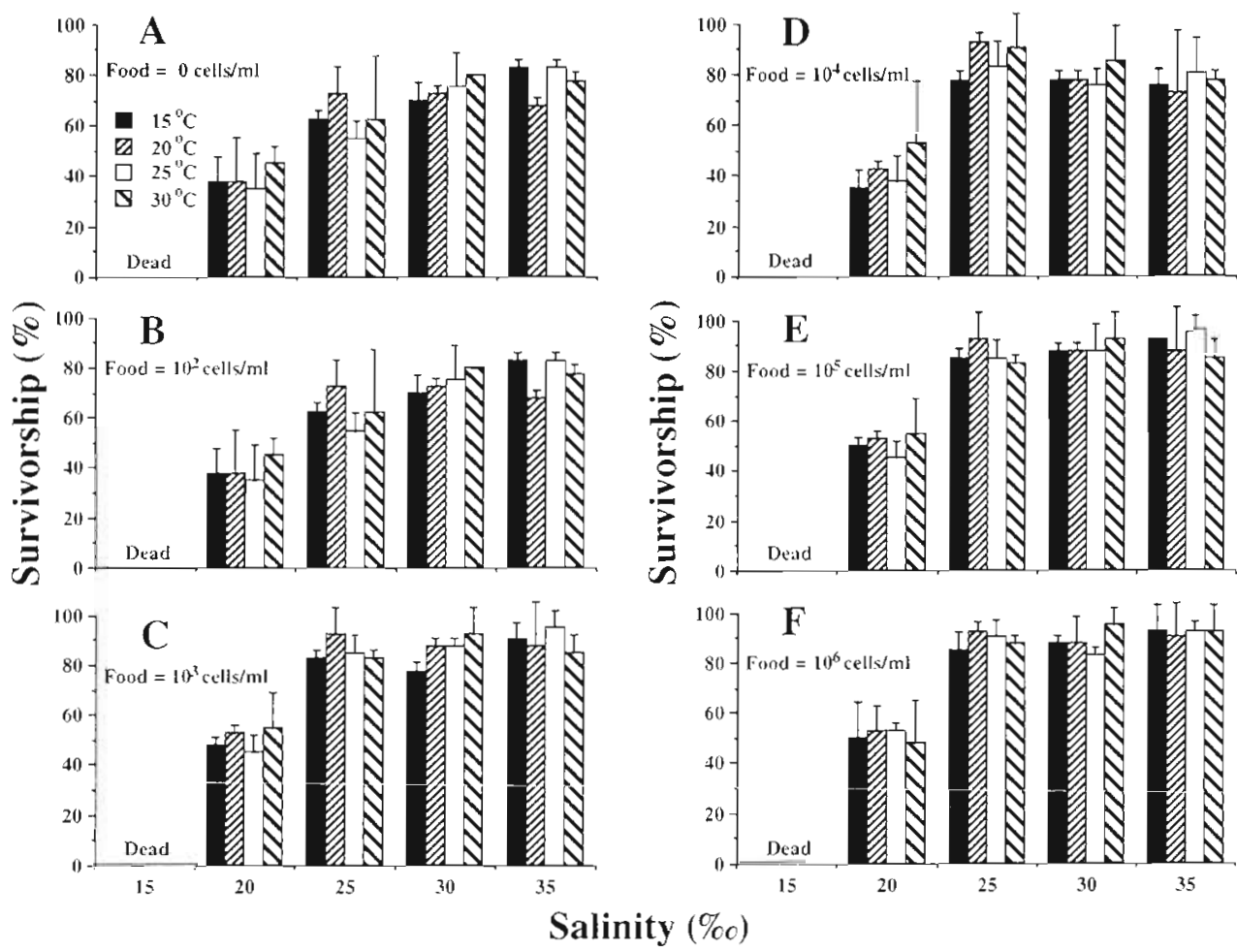

Fig. 2. Hydroides elegans. Expt IV: Effects of food concentration, salinity and temperature on survivorship from trochophore to newly-settled juvenile. Trochophores all died at salinity of $15 \%$. Data are plotted as means + SD of 2 replicate cultures (each started with 20 individuals!

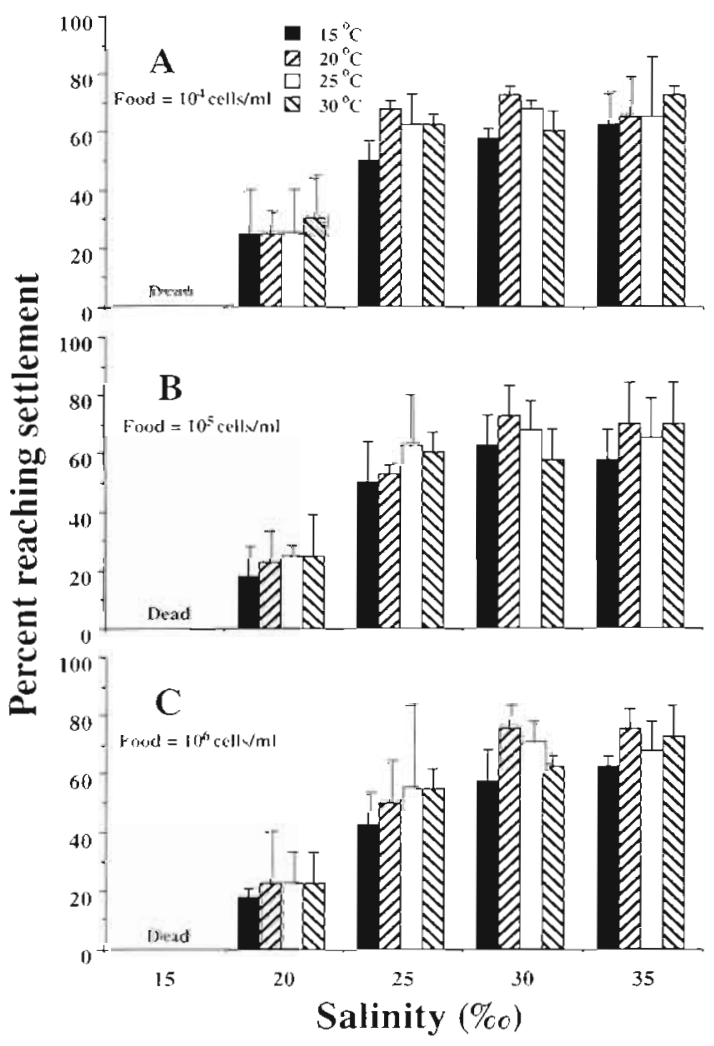

Fig. 3. Hydroides elegans. Expt IV: Effects of food concentration, salunity and temperature on percent reaching settlement from trochophore to newly-settled juvenile. Data are plotted as means + SD of 2 replicate cultures (each started with 20 individuals) the duration of development were affected by temperature (Table 3). Percent trochophores reaching settlement was lower at the $15^{\circ} \mathrm{C}$ treatment than at the 3 higher temperature treatments (Fig 3) Duration of development was longest at $15^{\circ} \mathrm{C}$, but progressively shorter with increasing temperature (Fig. 4)

Salinity strongly affected survivorship, percent reaching settlement, as well as duration of development (Table 3). None of the trochophores survived at $15 \%$. At $20 \%$, less than $40 \%$ survived to the end of experiment; at 25 to $35 \%, 80$ to $100 \%$ trochophores survived. Not all trochophores that survived through the experiment settled and began sessile life: only about 20 to $30 \%$ of the trochophores settled at $20 \%$; 42 to $67 \%$ settled at $25 \%$; and 57 to $75 \%$ settled at 30 and $35 \%$. Duration of development was about $7.5 \mathrm{~d}$ at $20 \%$; $6.7 \mathrm{~d}$ at $25 \%$; and $6.1 \mathrm{~d}$ at 30 and $35 \%$

Food concentration affected survivorship, percent settlement and duration of development (Table 3, Figs. 2 to 4). Survivorship of trochophores increased with increasing Isochrysis galbana concentrations from 0 to $10^{6}$ cells $\mathrm{ml}^{-1}$. Except at $15 \%$ salinity where all trochophores died, at food concentrations $\leq 10^{3}$ cells $\mathrm{ml}^{-1}, 35$ to $95 \%$ larvae survived through the $10 \mathrm{~d}$ experiment (Fig. 2). However, none of the survivors in treatments with $\leq 10^{3}$ cells $\mathrm{ml}^{-1}$ were able to settle. Percent reaching settlement was similar at algal concentrations $\geq 10^{4}$ cells $\mathrm{ml}^{-1}$. Trochophores at food concen- 


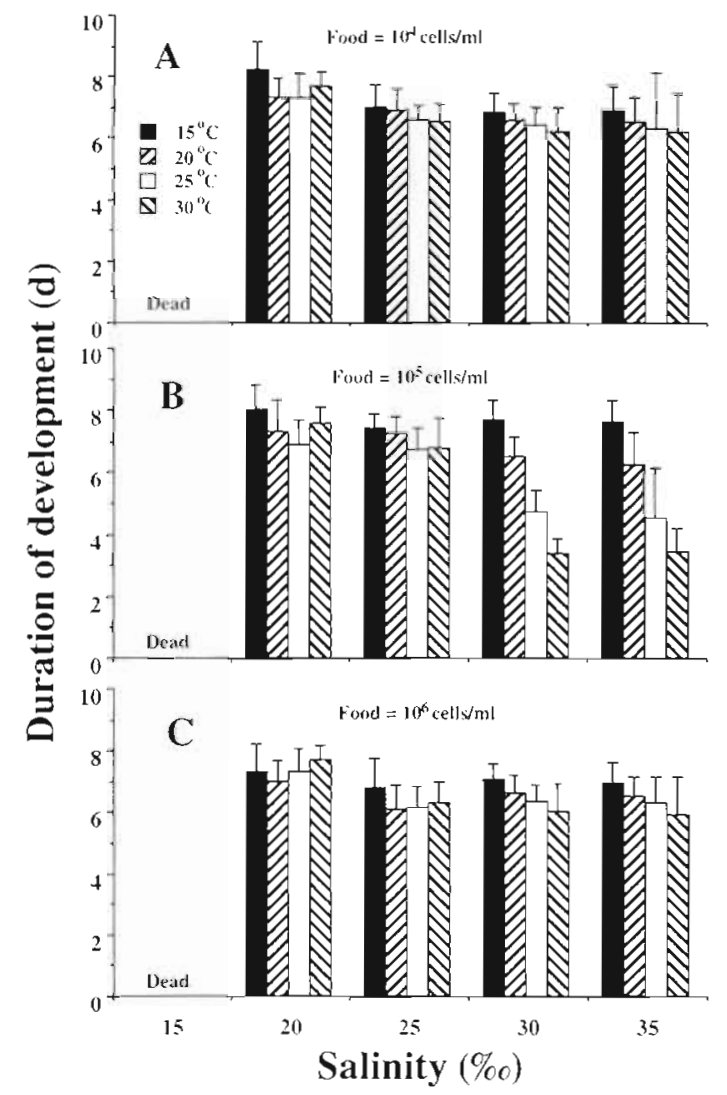

Fig. 4. Hydroides elegans. Expt IV: Effects of food concentration, salinity and temperature on duration of development from trochophore to newly-settled juvenile. Data are plotted as means + SD of 2 replicate cultures (each started with 20 individuals)

tration of $10^{5}$ cells $\mathrm{ml}^{-1}$ developed fastest. Those at $10^{4}$ and $10^{6}$ cells $\mathrm{ml}^{-1}$ had a similar but longer duration of development.

Interaction between food and salinity, and between salinity and temperature was detected for survivorship, with the highest survivorship found at higher salinities and higher food concentrations (Table 3 , Figs. 2 to 4). Interactions between food and salinity, between food and temperature, between salinity and temperature, and among food, salinity and temperature were detected for duration of development, with the fastest rate of development $(3.43 \pm 0.79$ and 3.39 \pm 0.5 d) found at $30^{\circ} \mathrm{C}$ temperature, 30 and $35 \%$ salinity, and $10^{5}$ cells $\mathrm{ml}^{-1}$ Isochrysis galbana (Table 3 , Fig. 4)

At the end of the $10 \mathrm{~d}$ experiment, none of the survivors at food concentrations $\leq 10^{3}$ cells $\mathrm{ml}^{-1}$ had settled. When feeding was resumed for an additional $7 \mathrm{~d}$ with Isochrysis galbana $\left(10^{5}\right.$ cells $\left.\mathrm{ml}^{-1}\right)$, settlement still did not occur These larvae gradually died off. Few larvae survived to Day 7, and those that did had become sluggish.

\section{DISCUSSION}

In many places, peaks of Hydroides elegans settlement occur in summer or autumn (Skerman 1958, Wisely 1958, Reish 1961, Kawahara 1969, Li et al. 1982, Zhang et al. 1984), and coincide with the high water temperature. In Hong Kong, however, settlement of $H$. elegans peaks in early spring to early summer when the seawater temperature is still low and salinity is high (Greene \& Morton 1976, Hon 1978, Qian unpubl. dataj. Structures submerged in Hong Kong waters for several months during winter and spring can be coated by $H$. elegans with a thickness and wet-weight reaching $3.8 \mathrm{~cm}$ and $12.5 \mathrm{~kg} \mathrm{~m}^{-2}$, respectively (Wang \& Huang 1993). However, only few individuals survive through the summer (Greene \& Morton 1976). The sharp decline in $H$. elegans adult population and larval settlement in summer could be due to the drastic drop in salinity caused by heavy rainfall and large amount of fresh water input from the Pearl River during these months. This argument is supported by both laboratory experiments and field surveys. For example, Mak \& Huang (1982) exposed naked $H$. elegans adults to salinities from 0 to $26 \%$ for up to $50 \mathrm{~h}$ and concluded that the lowest salinity in which $H$. elegans populations could grow was between 15 and $20 \%$. We carried out a similar experiment, but used $H$. elegans adults with intact tubes (Qiu \& Qian unpubl. data). Worms were placed in 24 combinations of salinity (10 to $35 \%$ ) and temperature $\left(15\right.$ to $\left.30^{\circ} \mathrm{C}\right)$ for $72 \mathrm{~h}$. Temperature had no effect on survival. Over $85 \%$ of adult survival was obtained at salinities $\geq 20 \%$, but at salinities $\leq 15 \%$, all worms died within $24 \mathrm{~h}$. A survey (Wang \& Huang 1993) of the fouling community in Hong Kong and adjacent waters showed that $H$. elegans did not occur in the western waters where fresh water input from the Pearl River is high, and the salinity can drop to below $10 \%$ during the wet summer season. $H$. elegans occurred only in the central and eastern waters where salinity is closer to oceanic level (Fig. 5). The experiments and field survey suggest that low salinity in summer may adversely affect the survival of $\mathrm{H}$. elegans in Hong Kong waters.

Our experimental salinities ( 15 to $35 \%$ ) and temperatures $\left(15\right.$ to $\left.30^{\circ} \mathrm{C}\right)$ and food concentration $\left(0\right.$ to $10^{6}$ cells $\mathrm{ml}^{-1}$ ) were selected to cover the ranges that Hydroides elegans larvae would likely experience in Hong Kong waters (Morton \& Morton 1983, Thompson 1986, Cai 1990). Low salinity reduced survivorship and percent reaching settlement, and lengthened duration of development. The tolerances to experimental salinities, however, were different among developmental stages. Development from newly-released oocyte to 2-cell, from 2-cell to blastula, from blastula to trochophore, and from trochophore to newly-settled juvenile failed 


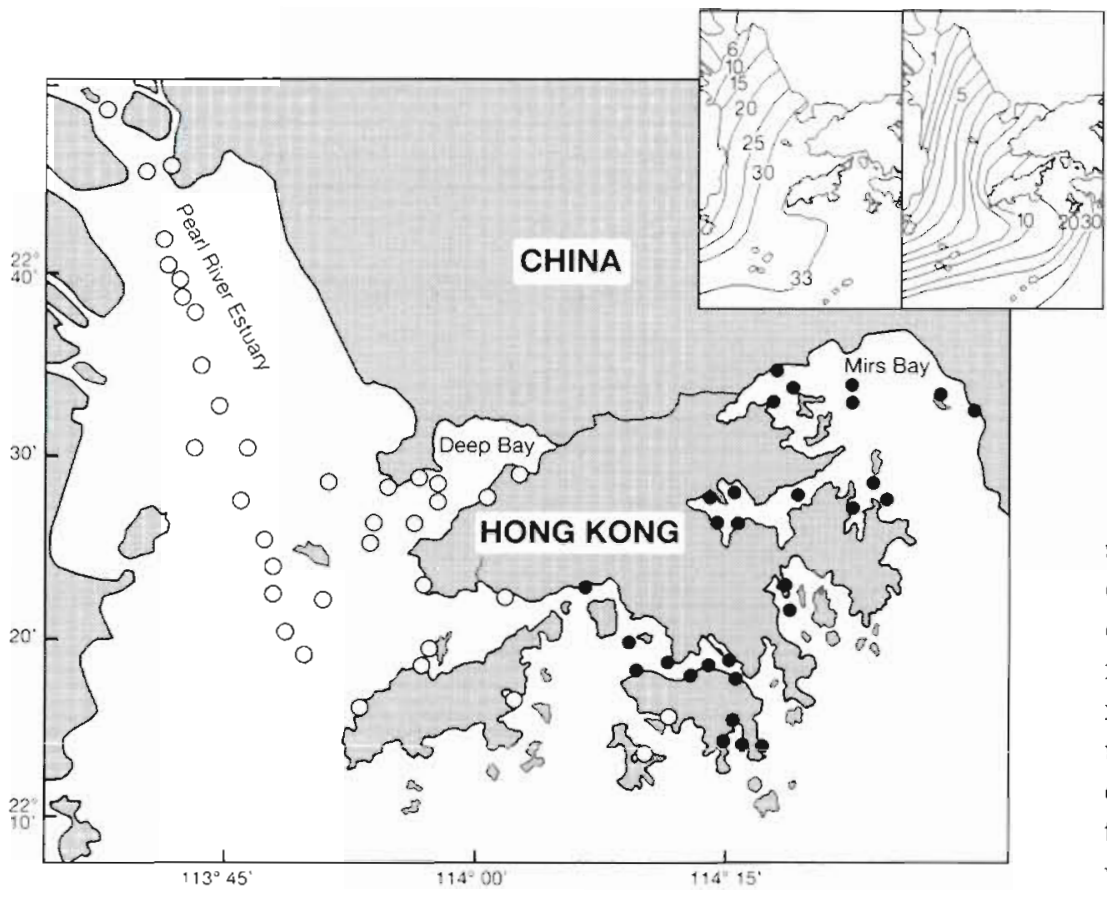

Food concentration affected survivorship, percent reaching settlement and duration of development. Survivorship of trochophores increased with increasing Isochrysis galbana concentrations from 0 to $10^{6}$ cells $\mathrm{ml}^{-1}$. At concentrations $\leq 10^{3}$ cells $\mathrm{ml}^{-1}$, no settlement occurred. This indicates that there is a threshold of food concentration below which larval development and settlement is compromised. In Hong Kong waters, the settlement peak com-

at salinities of $\leq 20, \leq 20, \leq 25$, and $15 \%$, respectively (Figs. 1 \& 2). Among these 4 larval stages, blastula to trochophore appears most likely to be limited by low salinity, as the lower limit for development to trochophore was 25 to $30 \%$, higher than the lower salinity limits for other embryonic stages and larval stage. Our results suggest that salinity can be the limiting factor for the early development of $H$. elegans in this area. The decline in salinity in Hong Kong waters during the summer monsoon could be responsible for the decline in settlement of $H$. elegans. Since the salinity resistance of the blastulae (25\%) was much lower than that of the juveniles $(15 \%$ ) and adults $(1.5 \%)$, the blastula stage during embryonic development is most likely to be affected when salinity drops in the field. However, it still remains unclear how salinity and temperature will affect the reproductive output of $H$, elegans adult, which may alternatively affect the settlement in the field.

In contrast, although temperature effects were evident on the duration of development in both embry onic and larval stages, in. which higher temperature led to faster rate of development (Figs. 1 to 3, Table 2), temperature had no effect on survivorship. Even at the lowest temperature $\left(15^{\circ} \mathrm{C}\right)$, there was still a considerable number of embryos and larvae developed through the respective stage (Figs. 1 to 4 ). Our results suggest that temperature is not a limiting factor for early development and settlement of Hydroides elegans in this area, and may not be responsible for the decline of settlement in field populations during the summer. mences in early spring, coinciding with the spring phytoplankton bloom (Thompson 1986, Cai 1990) which produced concentrations close to or above $10^{3}$ cells $\mathrm{ml}^{-1}$. Adverse effects of food limitation have been shown in many invertebrate species (cf. reviews by Pechenik 1987, Strathmann 1987). Extended duration of starvation may cause irreversible damage to larvae. For example, the larvae of 2 other polychaetes, Capitella capitata and Polydora ligni, were studied in laboratory experiments (Qian \& Chia 1991). Although larvae survived at a wide range of phytoplankton concentrations 10.5 times to 50 times ambient seawater concentration), settlement accurred only at phytoplankton $\geq 10$ times ambient seawater concentration for $C$. capitata and $\geq 5$ times ambient concentration for P. ligni. Food-limited larvae of both species had higher mortality, grew poorly, had a lower settling rate, and a prolonged larval life span. In this study, larvae that were allowed to resume feeding after being kept in the culture with little or no I. galbana for $10 \mathrm{~d}$ did not settle. It appears that $10 \mathrm{~d}$ of food limitation exceeds the point at which $H$. elegans larvae retain the ability to develop to competence. For $C$. capitata and $P$. ligni, however, over $50 \%$ larvae were still able to complete metamorphosis if feeding resumed after 1 or 2 wk of starvation (Qian \& Chia 1993).

Interaction between temperature and salinity on survivorship of Hydroides elegans was not detected in the experiments. However, interaction of temperature and salinity on duration of embryonic development from 2 cell to blastula (Table 2, Fig. 1d) was observed, with 
the quickest development achieved under high temperature and high salinity conditions. Interactions between food and salinity, between food and temperature, between salinity and temperature, and among food, salinity and temperature were also detected for duration of larval development, with the fastest development occurring at a temperature of $30^{\circ} \mathrm{C}$, salinity $\geq 30 \%$, and $10^{5}$ cells $\mathrm{ml}^{-1}$ Isochrysis galbana (Table 3 , Fig. 4).

Interaction among environmental factors may significantly influence larval settlement patterns of Hydroides elegans. In places where seasonal salinity fluctuations are minor, the population dynamics of $H$. elegans may be more dependent on the interaction of temperature and food. This explains the occurrence of settlement peaks in summer or autumn in many places (Skerman 1958, Wisley 1958, Reish 1961, Kawahara 1969, Li et al. 1982, Zhang et al. 1984). In Hong Kong waters, however, the drop in salinity during the summer appears to override the benefits of high temperature and results in the mortality of embryos, and eventually the decline in $H$. elegans settlement. From winter to early summer, the temperature in Hong Kong waters $\left(>15^{\circ} \mathrm{C}\right.$ ) does not limit early development of $H$. elegans and salinity is optimal ( $\cong 34 \%$ ). A peak in settlement commences in early spring, corresponding to spring phytoplankton bloom (Thompson 1986, Cai 1990). This suggests that the increase in phytoplankton concentration from early spring to early summer may contribute to the formation of settlement peaks. Temperature, however, does not seem to be a limiting factor for early development and settlement of $H$. elegans in this area.

Acknowledgements. The authors thank M. Hadfield, E. Holm, D. Rittschof, and X. Yang for assistance in algal and larval culture, L. Gosselin, D. Rittschof, M. Hadfield, S. Chiu, and 4 anonymous referees for comments on the manuscript, $Z$. Huang for allowing us to use his data on distribution of Hydroides elegans in Hong Kong, S. Chiu for technical support, and I. Ni and M. Wong for statistical consultation. This study was supported by a Croucher Foundation grant (CF94/ 95, SC-17) and a RGC grant (HKUST 574/95M) to P.Y.Q

\section{LITERATURE CITED}

Cai BJ (1990) Planktonic larvae in Daya Bay. In: Thurd Instıtute of Oceanography, State Oceanic Adminıstration (ed) Collections of papers on marine ecology in Daya Bay (Il). Ocean Press, China, p 232-236

Fauchald K (1977) The polychaete worms: definitions and keys to orders, families and genera. Nat Hist Mus Los Angel Cty Sci Ser 28:1-190

Greene GW, Morton BS (1976) Preliminary fouling and corrosion studies of painted metals in Hong Kong harbour. In: Romanovsky MV (ed) Proceedings of the IV international congress on marine corrosion and fouling, Juan-lesPins, Antibes, Frances. Centre de Recherches et d'Etodes
Oceanographiques, p 225-236

Hadfield MG, Unabia CC, Smith CM, Michael TM (1994) Settlement preferences of the ubiquitous fouler Hydroides elegans. In: Thompson MF, Nagabhushanam R, Sarojni $R$, Fingerman $M$ (eds) Recent developments in biofouling control. AA Balkema, Rotterdam, p 65-74

Haswell WA (1888) Embryology of Vermilia caespitosa and Eupomatus elegans. Proc Linn Soc NSW 22:1032-1034

Hedley RH (1956) Studies of serpulid tube formation. 2. The calcium-secretory gland in the peristomium of Spirorbis, Fiydroides and Serpula. Q J Microsc Sci 97:421-427

Hill MB (1967) The life cycle and salinity tolerance of the serpulids Mercierella enigmatica Fauvel and Hydroides unicinata (Philippi) at Lagos, Nigeria. J Anim Ecol 36: $303-321$

Hon SSL (1978) Aspects of marine fouling and antifouling in Victoria Harbour, Hong Kong. MPhil thesis, University of Hong Kong

Hurlbut CJ (1991) Community recruitment: settlement and juvenile survival of seven co-occurring species of sessile marine invertebrates. Mar Biol 109(3):507-516

Imajima M (1976) Serpulinae (Annelida, Polychaeta) from Japan. I. The genus Hydroides. Bull Natn Sci Mus Tokyo A. 2(4):229-248

Kawahara T (1969) Studies on the marine fouling communities, IV Differences in the constitution of fouling communities according to localities. a. Nagasaki harbour. Rep Fac Fish Prefect Univ Mie 6(3):109-126

Kinne $O(1970)$ A comprehensive treatise on life in oceans and coastal waters. In: Kinne $O$ (ed) Marine ecology. Vol I. Environmental factors, Part 1 Wiley-Interscience, London

Kinne O (1971) A comprehensive treatise on life in oceans and coastal waters. In: Kinne O (ed) Marine ecology. Vol I. Environmental factors, Part 2. Wiley-Interscience, London

Knight-Jones P, Knight-Jones W, Ergen Z (1991) Sabelliform polychaetes, mostly from Turkey's Aegean coast. J Nat Hist 25(4):837-858

Leone DE (1970) The maturation of Hydroides dianthus. Biol Bull (Woods Hole) 138:306-315

Li CY, Huang ZG, Zhang LX, Li FR, Zhen CX, Zhou NQ, Sun LC, Luan RX (1982) Research on the fouling organisms in Lushun harbor. Acta Ecologica Sinica 2(1):58-65

Mak PMS, Huang ZG (1982) The salinity tolerance of the serpulid polychaete, Hydroides elegans (Haswell, 1883), and its possible applications in bio-antifouling. In: Morton BS, Tseng CK (eds) Proceedings of the First International Marine Biology Workshop: The marine flora and fauna of Hong Kong and southern China, Hong Kong, 1980. Hong Kong University Press, Hong Kong, p 817-823

Miura T. Kajihara T (1981) The development of a serpulid worm, Hydroides ezoensis (Annelida, Polychaeta). Proc Jap Soc Syst Zool 20:7-12

Miura T, Kajihara T (1984) An ecological study of the life histories of two Japanese serpulid worms, Hydroides ezoensis and Pomtoleios kraussii. In: Hutchings P (ed) Proceedings of the First International Polychaete Conference, Sydney. The Linnean Society of New South Wales, Sydney, p 338-354

Mohan PC, Aruna C (1994) The biology of serpulid worms in relation to biofauling. In: Thompson MF, Nagabhushanam $R$ Sarojni R, Fingerman $M$ (eds) Recent developments in biofouling control. AA Balkema, Rotterdam, p 59-64

Morton B, Morton J (1983) The sea shore ecology of Hong Kong. Hong Kong University Press

Nordback K (1956) On the oogenesis and fertilization of the serpulid Hydroides norvegica (Gunnerus). Nytt Mag Zool (Oslo) 14:121-123 
Pechenik JA (1987) Environmental influences on larval survival and development. In: Giese AC, Pearse JS, Pearse VB (eds) Reproduction of marine invertebrates, Vol 9. Blackwell Scientific Publications, Palo Alto, CA, p 551-608

Qjan PY, Chia FS (1991) Effects of food concentration on larval growth and development of two polychaete worms, Capitella capitata (Fabricius) and Polydora ligni Webster Bull Mar Sci 48(2):477-484

Qian PY, Chia FS (1993) Larval growth and development as influenced by food limitation in two polychaetes: Capitella sp. and Polydora ligni. J Exp Mar Biol. Ecol 166:93-105

Reish D (1961) The relationship of temperature and dissolved oxygen to the seasonal settlement of the polychaetous annelid Hydroides norvegica (Gunnerus). Bull Sth Calif Acad Sci 60(A):1-11

SAS (1988) SAS/STAT user's guide, Released 6.03 edition. SAS Institute Inc, Cary, NC

Scheltema RS, Williams IP, Shaw MA (1981) Gregarious settlement by the larvae of Hydroides dianthus (Polychaeta: Serpulidae). Mar Ecol Prog Ser 5(1):69-74

Skerman TM (1958) Marine fouling at the port of Lyttleton. NZ J Sci 1:224-257

Strathmann RR (1987) Larvai feeding. In: Giese AC, Pearse JS, Pearse VB (eds) Reproduction of marine invertebrates,

This article was submitted to the editor
Vol 9. Blackwell Scientific Publications, Palo Alto, CA p $465-550$

ten Hove HA (1974) Notes on Hydroides llegans (Haswell 1883) and Mercierella enigmatica Fauvel, 1923, alien serpulid polychaetes introduced into the Netherlands. Bull Zool Mus Univ Amsterdam 4(6):45-51, 9 Figs

ten Hove HA, Hiemstra F, van Soest RV M (1991) Towards a phylogeny of the genus Hydroides (Fam. Serpulidae). Bull Mar Sci 48(2):589

Thompson GB (1986) The 1976/77 phytoplankton cycle in Aberdeen Harbor, Hong Kong. Asian Mar Biol 3:33-45

Wang JJ, Huang ZG (1993) Fouling polychaetes of Hong Kong and adjacent waters. Asian Mar Biol 10:1-12

Wisely $B$ (1958) The development and settling of a serpulid worm, Hydroides norvegica Gunnerus (Polychaeta). Aust J Mar Freshwat Res 9:351-361

Zar JH (1984) Biostatistical analysis. Prentice Hall, Englewood Cliff.s. NJ

Zhang LX, Huang ZG, Li CY, Li F, Zheng CX (1984) ECological study of the fouling community in Yongxi, Xisha. Acta Oceanologica Sinica 5 (suppl):847-858

Zibrowious H (1973) Serpulidae (Annelida, Polychaeta) des cotes ouest de l'Afrique et des archipels voisins Ann kon Mus Midden-Afrika Tervuren (Zool) 207:1-93

Manuscript first received: December 9, 1996

Revised version accepted: April 16, 1997 